\title{
Impact of financial inclusion and financial stability: Empirical and theoretical review
}

\author{
Asghar Kamal* | Talat Hussain | M. Mahmood Shah Khan \\ Department of Banking and Finance, School of Business and Economics, University of Management \\ and Technology (UMT), Lahore, Pakistan. \\ *Correspondence Emails: asgharkamal5523@gmail.com | ktk_asghar6946@yahoo.com
}

\begin{abstract}
The foremost objective of this research is to review the connection among the financial inclusion (FI) and banks financial stability (FS). The research article surveys a vest body of literature devoted to evaluating the relationship of among the FI and FS of the banks. The literature review evaluates recent empirical research studies on the impact of FS and banks FS. The research works divided into following part (i) What is financial inclusion (FI) (ii) What is financial stability (FS) (iii) the influence of FI and FS (iv) FI measurement and indicator (v) whether FI lead to enhance the FS. This paper presents the relevant review of imperialistic research on the nexus among the influence of FI on FS since the period of 1995-2020. Abundant research studies to date suggest that FI has positive and significant impact on FS of the banks' stability. While few other research study also reveals that when FI have negative influence on the FS is due to the without having efficient management when the credit is expanded in this time it will increase the risk for financial stability.
\end{abstract}

Article History

Received:

March 2, 2021

Last Revised:

June 18, 2021

Accepted:

June 20, 2021

Published:

June 30, 2021

Keywords: financial inclusion, financial inclusion indicators, financial inclusion measurement, financial stability, banks financial stability, impact of financial stability.

\section{How to Cite:}

Kamal, A., Hussain, T., \& Khan, M. M. S. (2021). Impact of financial inclusion and financial stability: Empirical and theoretical review. Liberal Arts and Social Sciences International Journal (LASSIJ), 5(1), 510-524. https://doi.org/10.47264/idea.lassij/5.1.33

\section{Publisher's Note:}

IDEA PUBLISHERS (IDEA Journals Group) stands neutral with regard to the jurisdictional claims in the published maps and the institutional affiliations.

\section{Copyright:}

(C) 2021 The Author(s), published by IDEA PUBLISHERS (IDEA Journals Group).

This is an Open Access article published under the Creative Commons Attribution-NonCommercial 4.0 International License (http://creativecommons.org/licenses/by-nc/4.0/) 


\section{Introduction}

FI concept has gained much attention from the last few decades 2000s, empirical evidence finding reveals that FI influence and significant positive and reduces the poverty from the country (Shiimi, 2010). The current study has few parts (a) financial inclusion (b) financial stability (c) How to measure the financial inclusion and what are the indicators (d) Fi influence on banks stability. In financial literature the financial inclusion is playing active role; however, there is not recognized definition of FI in the past literature (Tita \& Aziakpono, 2017). FI is denoting the financial service access to both level in the society discrete level as well as the business level of financial produced and service of the financial institution like transaction, payment, saving, credit and insurance at an affordable cost (Alex Bank, 2017). FI is designates a state where the bulk of financial product research to the society (Olaniyi, 2017). The main impartial drive of the FI is to improve the social life of the individual and household wellbeing, increases the activity the SME, increases the employment opportunities and economic growth of the entire country.

The research works defined that, FI is basic financial service of the financial sectors to be provided it low and affordable and low cost to the weaker section of the population with any discrimination (Rangarajan, 2008). The term FI is means the financial product and service such is debit card credit card to the enormous segment at an affordable cost in the population (Chhabra, 2015). The main purpose of the FI is the access to financial service and product to that type of the group whose is excluded from the financial service in the society, FI include on the saving and payment of accounts, credit insurance, pension and ATM (Ambarkhane et al., 2014). However, some other research works explain that FI is the easily access to the availability and accessibility of the financial service at reasonable cost to entire segment of the population (Sarma, 2008). Enhancement in the FI service will lead to higher rate of saving, increasing in capital, reduction poverty, improvement on well-being, increases in employment rate, improve the economic development and lead to the economic growth (Park \& Mecado, 2018). Other research work also examines that FI is the easy access to the financial product and service to the entire society including the weaker group of the society at cheap cost and without any judgment (Chakrabarty, 2013).

FI is the financial service for the society where the member of the can use in effectively and efficiently use (Demirguc-Kunt et al., 2017). However, other examiner also defines as, that FI is easy access and availability to the financial service of all members of society included member who is excluded from the basic financial service in the different reason (Ozili, 2018). Some other scholars also define that the FI is basic banking financial service to all member of the society at a cheap cost and without disadvantage and low-income groups (Dev, 2006). The research studies indicate from the research that financial inclusion (FI) focused on the access and available of financial to each member of the society at affordable cost. FI will bring the population of the society to the formal financial service that haven't access to financial product and service in the society (Allen et al., 2016). However, the examiner examines that only one factor is not sufficient, FI is the procedure there every member of the society positively and equally contributed and help the weaker section of the society (Sarma, 2012). However, other research study examines that access to the financial service to the entire section of the society to contribute in the economy (Sarma, 2008).

FI many research studies defined it is the access to the basic financial product and service including to both level in society such is individual and enterprise level in the society (Kim, 
2016). In the modern economic system, everyone is participated in financial inclusion activity. FI is familiar as a System that bring enhancement in the quality, quantity and efficiency in financial intermediary service (Babajide et al., 2015), which turn to lead to improve lives, more opportunity and enhance the economic growth of the country. Babajide et al. (2015) reveal that FI bring increase in saving and investment and local business. Moreover, research study also reveals that technological innovation also bring improvement in access to finance such as ATM, ATM cards, debits cards, prepaid card (Frame et al., 2018). Moreover, the term FI is the state of access to the financial product and service at low and affordable cost to the entire population without any discrimination (Aduda \& Kalunda, 2012). The main purpose behind the FI is bringing increase in the access to the financial product and service to population without any discrimination (Hariharan \& Marktanner, 2012).

FI define' where financial product and service can provide to the whole society without any discrimination the segment of the society who could not use financial inclusion is the banking product and service where entire population takes the benefits from them (Kama \& Adigun, 2013). FI is also define, the financial delivery of the financial service at affordable cost to the member of the society who is excluded from the basic financial service (Dev, 2006). Moreover, few other research studies also examine that the FI is process operating the financial accounts for the well-being of the individual (Allen et al., 2012).

The ease accesses to the finance will alleviate the income inequality from the society (Kim, 2016). FI is alleviating the income inequality and reduce the poverty from the society (Beck et al., 2007). Financial inclusion bring enhancement in the economic growth and development in country (Khan, 2011). FI is means the financial product and service at a low and affordable cost to weaker section in the society, both can access in society individual and firm level (Seman, 2016). Numerous, research also examine that the FI is means the access to financial service at low cost to low segment of the society (Sharma \& Kukreja, 2013). Moreover, the research works also defined that FI is state where financial product and service at reasonable cost to entire population such as debit cards, credit card, formal saving, payments pension funds and insurance (Umar et al., 2019). Similarly, numerous studies show that Islamic finance only can attract the segment of society who are excluded from the basic financial product and service due to religious reasons (Haneef \& Tahir, 2018). The research investigate that Islamic finance are key player to attract the excluded segment in the Muslim and non-Muslim countries.

\subsection{Financial stability}

The idea of the (FS) has taken attention of both policy-maker as well as the academia in the recent crisis of the 2007-2009. Due to the recent financial crisis around the globe, the financial stability has renewed interest on the priority of the research works around the world. Prior research work reveals that the financial stability contributes the main role in the development and sustainability of the countries. In the meantime, of financial crises, the standing position of the term financial stability has involved the consideration of scholars, legislators, and practitioners. After the financial crises of 2007-2008 the financial stability hottest topic for the research scholar and policymaker in developed and emerging markets (Beck et al., 2007). The author reveals that the FS is the ability to help the economic system that manage the risk in the country, absorb shock and allocate the resource (Houben et al., 2004). FS is the broad terminology it consists of three different dimension of the financial system (i) financial market (ii) financial institution (iii) financial infrastructure (Houben et al., 2004). However, other study refers that institution depended on the FS and FS is made the financial system of the 
country (Crockett, 1997). Additionally, the research study finds the correlation among the financial access and FS in the data of the SME in Armenia (Morgan \& Pontines, 2014).

The prior studies measure the FS through different technique through banks Z-score and nonperforming loan (NPL). Furthermore, author argued that FS is a state where financial shock could control by the financial system of the country it's include in financial markets and intermediaries and infrastructure (Anatolyevna \& Ramilevna, 2013). According to the research efforts the term financial stability of banks is, the gap exist is from the bankruptcy or actual failure (Beck et al., 2007). Furthermore, the research shows that financial stability is the spectrum variation eventually and reliable with manifold mixtures of its essential elements, shows that the capability to help the economic system assign capitals succeed risks and absorb shocks (Houben et al., 2004). Author argued that the FS is key pillar and pathway to the economic stability of the countries (Popovska, 2014). Therefore, research shows that FS is the ability of resistant to financial shock of the financial institution. According to research, the term financial stability of banks is, the gap exist is from the bankruptcy or actual failure (Beck et al., 2007). Furthermore, the research effort also shows that the financial stability is the spectrum variation eventually and reliable with manifold mixtures of its essential elements, shows that the capability to support the economic system assigns capitals succeed jeopardies and fascinate shocks (Houben et al., 2004). Furthermore, the research works reveals that the FS is considered as the state in financial market, to "absorb shock, without triggering a failure of financial institutions, financial markets and payment structures (Motelle \& Biekpe, 2015).

\subsection{Glance of comparison of Islamic and conventional banks}

The research analysis from prior works that Islamic banks is much stable than the conventional banks (Rashid, 2020; Ramlan \& Adnan, 2016). No doubt, financial stability is playing a significant role in the efficient financial system and economic growth of the country. Such is study reveals that the financial stability of the banking sector not only enhances the economic growth of country side by side the financial stability increases capability to sustain the internal and external shock but lead to achieve local financial stability and global financial stability (Athanasoglou et al., 2008). Similarly, the research also finds that the main reason of behind the Islamic banking stability is the diversification of the asset (Ghassan \& Taher, 2013). Islamic banks efficiently manage the risk in the financial crisis of 2007-2008 (Rahim \& Zakaria, 2013; Mirza et al., 2015). Taken a sample of 46 Islamic and 71 conventional banks which is operating operation in the GCC countries from the period of 2005-2017, the examiner research reveals that on average the Islamic banks are more profitable than counterpart (Hadriche, 2015).

Numerous studies have done a comparative investigation on the Islamic and conventional banks. For instance, the authors examine that the Islamic banks are better performed then the conventional banks in terms of profitability and stability (Safiullah, 2010). However, the research study also reveals that Islamic financial system superiorly perform then the counterpart financial system, due to the less risky and better regulation (Erol et al., 2014). Further, the research work also examine that the conventional banks are more profitable than Islamic bank due to the large capital and market size (Johnes et al., 2014). Similarly, some of the researchers claim that Islamic and conventional banks are insignificant in terms of profitability (Hamid \& Azmi, 2011). While some of the researcher's treat the Islamic and conventional bank in same realm in terms of efficiency (Rozzani \& Rehman, 2013). Financial stability and access to financial service becoming a priority from the researcher and financial policymakers from last few decades, Manifold research studies explore from the research work 
that financial inclusion have affect the economic inequality, poverty reduction, economic growth and financial stability. The article overview various research worldwide a whether financial inclusion enhance the financial stability of banking sectors. First research article ask that what is financial inclusion. Financial inclusion is the financial inclusion service initiative by the local government for to ease access to the financial product and service to entire population without any discrimination.

This research mentions the different indicator of the financial inclusion. The secondly, financial stability is resistance to the financial shock in financial sectors. Thirdly, numerous research studies have done that FI constructive impact on the FS of the financial sectors. Financial inclusion enhances the financial stability of the financial sectors such (Demirguc-Kunt et al., 2017; Ditta \& Saputra, 2020; Ikram \& Lohdi, 2015; Le et al., 2019; Shihadeh et al., 2018; Yousef, 2020). The basic research questions of the research study are: (a) what is financial stability and theory? (b) What is the financial inclusion and measurement approach? (c) Is there is an empirical connection among the FI and FS? (d) Whether any theoretical link among the FI and Banks stability?

\section{Theoretical approaches}

According to the research works the segment of the society who did not use the basic financial service are ultimately takes benefits from the financial inclusion (Bhandari, 2018). While little research studies also believe that females also take benefits from the financial service in the society (Demirguc-Kunt et al., 2017; Ghosh \& Vinod, 2017). Moreover, some research study also investigates that financial have positive impact on the country economic growth, financial stability and poverty reduction (Kim et al., 2018; Mehrotra \& Yetman, 2015). Several research studies empirical and theoretically established and analysis that FI enriches the financial stability of the banking sector. Below some financial inclusion theories that supported the links between the financial inclusion and financial stability.

\subsection{Public good theory}

Public good theory, the financial inclusion theory argued that (a) the basic financial service is easily access to the whole region and discrimination in the service (a) No restriction for anyone in the society every member takes benefits from the financial service. The theory claimed, that every member of will contributed in economy and no one can exclude from the basic financial service. According to the public good theory, all member of the society takes benefits from the financial inclusion service. The main financial inclusion service is Automated Teller Machine (ATM), Banks accounts, credit cards, debit cards and banks deposits.

\subsection{Financial intermediation theory}

The FI theory, the financial intermediation theory stated that the banks are working as an intermediary between individual and population. The financial intermediary theory is based on the transaction cost and information asymmetric.

\subsection{Dissatisfaction theory}

Financial access theory, the financial theory argued that financial access program in society only targeted the section of society who already use the financial service but left due 
dissatisfaction the from the financial service of the financial sector. Therefore, the financial inclusion theory claimed that focused on the section of the society who already engaged in previously in the financial service.

\subsection{Vulnerable group theory}

The financial access principle, that financial access program targeted the group of the society who vulnerable in the society such as young peoples, woman poor people, elder people who suffer from the financial crises. The group is the most effect group during the financial and economic crisis of 2007-2009. Therefore, the theory reveals that the financial inclusion initiative program targeted the weaker section of peoples in the society. Hence, the vulnerable theory brings the peoples who are affected during the economic recession of 200-2009 and bring a formal financial program.

\subsection{Echelon theory}

The echelon theory, the financial inclusion theory argued that the basic financial must be delivered to the section of the society who is excluded from the basic financial service. The financial service should on their communal leader because the community leader has influence on the society. The community will trust on their leader in society and give much respect to the leaders. The entire member of the society trust on the leaders and the member of the society think that the leader decisions were beneficial for the community.

\subsection{Public service theory}

The financial inclusion theory defines that the financial inclusion services are the public responsibility of the government initiative by where they impose on it. The public service claimed that financial inclusion is the financial service should be delivered to the entire without any discrimination to whole society. The public good theory state that the theory working for the welfare of the society and target the section whose is excluded from the basic financial service. The theory quantified, without the government support the financial inclusion program cannot be achieved, when the government takes the responsibility for the financial inclusion. When the economic and financial system is control by the government, then the financial inclusion accomplished.

\subsection{Special agent theory}

The theory of the financial theory argued that for the distribution of the financial service to the section of the society. A special type of the person hires for the delivery of the financial service to the section that are exclude from the financial service. The special agent theory, the theory claimed that the hire person should be highly skill full and the person has capability that brings the excluded population to formal financial service. The hired person has personal relationship with the principle. The special agent theory also claimed that the financial institution and technology is also play a significant role of the special person.

\section{Research methodology}

The main strategy of the current research article methodology, we first explained what financial stability is, what is financial inclusion, whether financial service enhance the financial stability 
of the banks. The currents research effort assesses 100 around article from the globe to examine the role of the financial access on the banking stability. The article has divided few stages. Such as indicator and measurements technique of FI and FS, the role of FI on the banking stability from the international research works. The research article reviews around one hundred over the time spam from 2000 to 2020 . The selection of articles from this research work is selected form the different research engine including Google Scholar, Science direct, emerald, and Springer link.

\section{Financial inclusion and financial stability: A discussion}

Growing body of research work found mixed consequences on the association amid the financial service and profitability/Performance. The researcher uses different countries and different proxies use in his research work. Stable financial system enhances the economic performance and wealth accumulation (Houben et al., 2004). According to research works examine that FI is the condition where the bulk of financial service spread and adequately huge segment of the population in the society (Olaniyi, 2017). The study established that the extension in using automatic Teller machine will increase the financial performance the banks Nigerian (Jegede, 2014). To investigate the impact of credit card on the banks performance of the Kenya the results examine that the credit card will improve the financial performance the bank of Kenya (Alfonse \& Florence, 2012). To explore the affiliation between financial performance and electronic-based banking, financial performance was measured through return on asset and return on equity. The research described that the electronic-based service has positive impact financial performance (Akhisar et al., 2015). The research advocates that the financial access to Islamic financial product have an affirmative relationship with FI in mostly Muslim countries (Mohseni-Cheraghlou, 2017).

Ahmed (2013) described that FI, use and access to finance, financial development and public policy not clear yet and expended. Taken the data of 5 Nigerian banks over the period of 20092015 using the "Panel Least Squares" technique the study concluded that ATM, Mobile Phone account have positive impact the commercial banks (Anyanwaokoro \& Ogbu, 2017). To scrutinize the link among the FI with the banks financial stability using PCA and common factor Analysis the results described that financial inclusion highly correlated with financial stability (Amidzic et al., 2014). Readdress the financial inclusion important and bring reform in in financial sector in Nigeria. The result of the research work reveals that financial inclusions improve the financial profitability. Taken sample of Nigerian bank to examine the role of credit card on the banks profit the research works examine that the credit card have positive impact on the bank profit (Akhisa et al., 2015; Yousef, 2020).

The data was taken from the 149 respondents and run regression analysis to check the impact of FI on banks profitability. The results of the study examine that financial inclusion not statistically significant but positive impact on the financial profitability (Ikram \& Lohdi, 2015). To explore the link among the Islamic financial banks with the FI the research work uses both the secondary as well as primary data for the research. The results of the research effort examine that Islamic finance repaid growth around the globe which ultimate lead to the economic growth (Nazer, 2017). The research used a Probit model to check the affiliation of FI, Islamic banking and finance of the OIC. The research works results examine that the Islamic banking system are more financially inclusion than conventional banks (Abdu et al., 2018). Nawaz (2018), Taken the data of 18 Islamic banking of Bangladesh and Pakistan run regression model the results of the research study reveals that in both countries Islamic banks are more 
engaged in financial inclusion than counterpart. To check that whether financial inclusion directly impacts the Islamic banks performance. The research work results examine that FI positively improve on the Islamic banks performance and sustainability (Shihadeh et al., 2018; Le et al., 2019; Ditta \& Saputra, 2020). Similarly, the research work also investigates to know that whether FI equally important in Islamic banks in Pakistan. We did not find such research that examines the link of access to finance and Islamic banks ROA in Pakistan context.

Last few decades, Islamic finance take great attention of the researcher and academia around the globe. The main principle Islamic banks around the world are to follow the principal profit and loss sharing (P/L). Such few contracts of Islamic bank are, Mudabrah contract, Musharakah contract, Musawamah, Salam and Ististna contract. Islamic banking is play key and dominant role in Pakistan economic growth. The research study reveals that financial institution play significant role and enhances economic growth, performance and batter allocation of the resource (Ahmed, 2010). Islamic financial systems have gained incredible attention due to its quick growth and expansion with a predictable increase of 15-20 percent annually both in Muslim and non-Muslim world (Lone \& Bhat, 2019). However, numerous the research studies reveal that one side Islamic gain repaid growth in the market while one other the Islamic finance is extremely suffering from the unbanked FI in Muslim countries as well as MENA area, Sub Saharan Africa and Central Asia (Ali et al., 2015). However, Islamic banking signifies positive relationship with the financial inclusion (World Bank, 2014). However, to check association between the Islamic finance and FI, the examiner reveals that technology, religious factor and Islamic finance product awareness has positive association (Shinkafi et al. (2019).

Research work found diverse outcomes on the association among the FI and FS. The researchers use different countries and different proxies use in his research work. Khan (2011) discloses from the research work that FI affirmative effect on the banks' stability. The foremost goal of Islamic banks and finance is to promote the well-being, establishing socio-economic and equal distribution of wealth and FS (IMF, 2018). Financial stability is the ability to helps the economic system allocate resource, manage risk and absorb the shocks (Houben et al., 2014). Financial stability is interconnected with the financial bubbles, or more generally, with volatility in financial market and those market bubbles impair financial market efficiency (Crockett et al., 2003). The research works also reveals that FS is comprehensive notion, which cover three main financial systems such financial market, financial infrastructure and financial institution Houben et al. (2004). Financial stability plays a significant and positive role in country GDP (Creel et al., 2015). Last few decades, financial inclusions have received a great attention from research field, politician, business sector and financial stakeholder. FI is the universal access to the financial product and service (e.g ATM, deposit, ATM machine etc.) at a reasonable cost (Sarma, 2008).

Moreover, the researcher also says that FI is the ease usage of financial service for entire society member (Ozili, 2018; Olaniyi, 2017). Taken the data from the small and median enterprises (SME) of Armenia the results of the study find that there is a parallel between the financial access and banks stability (Morgan \& Pontine, 2014). The research measured the financial stability is through z-score using GGM dynamic panel estimation of unbalance of small and median enterprises over the period of 2005 2011. The concept of the financial stability was the base study of the Back (2009), the researcher measured the financial stability through the zscore, where the measurement definition is taken liquidation jeopardy and non-performing loan ratio to the credit risk. The $\mathrm{Z}$ - score indicate the Standard deviation that banks ROA to drop below the expected value before the equity. The $\mathrm{z}$-score increase the high profit and 
capitalization level, reducing with unstable earning by the higher standard deviation of ROA (Ahamed \& Mallick, 2019).

Research have focused on the determinants of the FI in Africa (Zins \& Weill, 2016; Uddin et al., 2017). Moreover, the research efforts examine that FI is the access and usage of the finance. Around the world there is a different indicator of FI such is formal saving formal accounts, credit and insurance formal financial institution (Demirguc-Kunt \& Klapper, 2012). The FI is consist deposits, transaction account and financial service for the repayment purpose and saving money (Demirgu-Kunt et al., 2017). The term FI is the situation, the delivery of wide range of financial product and service at an affordable price such as saving, credit cards, remittance, insurance service and payment service (Sarma \& Pias, 2011). Research finds different results that there is non-liner relationship among the FS and financial stability (Ardic et al., 2013). Moreover, Al-Smadi (2018) shows that there is adverse effect of financial service on the financial stability. For the research results the researcher use fully modified least squares time series data. Financial stability is a condition where, financial shocks (e.g 2007-2008) could be resisted by a financial system that contains by the financial market, infrastructure and financial intermediaries (Anatolyevna \& Ramilevna, 2013). Study of Khan (2011) shows that when financial sector is efficient then the banks are performing a financial intermediation process among user and financial sector supported financial infrastructure. The research reveals that when financial system is not stable the system divested the economy of the country.

Prior research found mixed results on the relationship among the financial inclusion on banks stability and profitability. Financial performance was measured through the return on asset (ROA) and Return on equity, whereas for the measurement of the financial inclusion of the banks the research work uses six different indicators (Credit to Small and median enterprises, Automatic Teller machine (ATM), new service of ATM, and number of ATM, and number of credit) has significant impact on the financial performance (Shihadeh et al., 2018; Ussif \& Yussif, 2020). While other authors examined that financial inclusion has a positive impact on the bank return on equity (ROE). However, the results of the author reveal that there is affirmative relationship of financial inclusion index on bank return on asset (ROA) (Oranga \& Ondabu, 2018). Research described that the financial inclusion is good for the banks' financial stability (Wairimu \& Omagwa, 2020). Taken the data from the MENA region the research work examines that the financial inclusions have positive impact on the financial stability (Neaime \& Gaysset, 2017). While, Alvi et al. (2020) find out there is controversy connexion among the financial access and financial stability. Arun and Kamath (2015) took data from Indian commercial banks that financial inclusion boosts the GDP and sustainability. The author says that automatic Teller Machine is the key player in financial inclusion (Das \& Guha, 2015).

Gupte et al. (2012) says that FI is access to an inclusive choice of financial facility at a low and reasonable cost. Moreover there is little research work done that how financial inclusion affect the financial stability. However, use a GMM for the panel data from the African countries over the time period of 2004-2011. Financial stability was measure through the Z-score, finding of the research study show outstanding loan positive impact on the financial stability, whereas the deposit is negative impact on the banks' financial stability (Amatus \& Alireza, 2015). However, Mehrotra and Yetman (2015) Show that access to the basic financial service speed growth for the financial stability. Using cross- country data, Sahay et al. (2015) investigate that FI has negative impact on the stability of banking sectors. After that crisis, little research works done that whether financial inclusion affects the financial stability. Petersen and Rajan (1995) Says that financial inclusion is the element, which work for alleviate the injustice, promote the 
financial stability and reduce the information asymmetry. Theoretical research study done to check the relationship among the financial inclusion; the authors examine that technology effective financial access, service of Islamic financial, religious factor and awareness of Islamic financial product significant impact on the financial inclusion (Shinkafi et al., 2019).

\section{Conclusion}

The main objective of the current research effort is to evaluate the influence of financial service on the financial stability of banks from the time period of the 2000-2020. In the light of this research paper the affiliation among the financial access and banking stability is very relevant to the research community. The research work reviews the literature on the link between the FI and FS. Numerous research works explore that there is significant association among the FI and banking stability. The prior research works have measure the financial inclusion through ATM card, Debit card, ATM machine, banks deposit, insurance and finance to small and medium enterprise. In overall, the links between the financial inclusions on the financial stability of banks are still inconclusive due to the mixed results found in the literature. Numbers of number research works revels from the research works that financial inclusions have positive impact on the financial stability. However, on the other side some research study also examine that financial service has negative impact on the financial stability. The optimistic view for the financial inclusion on the financial stability based on the availability and accessibility of financial service in the banks sectors.

Furthermore, the research works reveals that the financial stability is considered as the state in financial market, to "absorb shock, without triggering a failure of financial institutions, financial markets and payment structures (Motelle \& Biekpe, 2015). Houben et al. (2004) says that the financial stability is broad concept, which cover three main financial systems such financial market, financial infrastructure and financial institution. Financial stability plays a significant and positive role in country GDP (Creel et al., 2015). Last few decades, financial inclusions have received a great attention from research field, politician, business sector and financial stakeholder. Financial inclusion is the universal access to the financial product and service (e.g ATM, deposit, ATM machine etc.) at a reasonable cost (Sarma, 2008). Stable financial system perform is financial mediation progression in the financial institution and financial infrastructure in the country (Khan, 2011). FS is the defined that, the ability to resist the financial shock for the financial institution and payment system (Motelle \& Biekpe, 2015).

\section{References}

Aduda, J., \& Kalunda, E. (2012). Financial inclusion and financial sector stability with reference to Kenya: A review of literature. Journal of Applied Finance and Banking, 2(6), 95-120. http://www.scienpress.com/Upload/JAFB/Vol\%202_6_8.pdf

Abdu, M., Jibir, A., Abdullahi, S., \& Rabi'u, A. A. (2018). Can Islamic banking and finance spur financial inclusion? Evidence from Sub-Saharan Africa. CBN Journal of Applied Statistics, 9(1), 77-104. https://www.econstor.eu/handle/10419/191712

Ahamed, M. M., \& Mallick, S. K. (2019). Is financial inclusion good for bank stability? International evidence. Journal of Economic Behaviour \& Organization, 157, 403427. https://doi.org/10.1016/j.jebo.2017.07.027.

Amidzic, G., Massara, M. A., \& Mialou, A. (2014). Assessing countries' financial inclusion standing-A new composite index. International Monetary Fund. 
Ahmed, H. (2013). Financial inclusion and Islamic finance: organizational formats, products, outreach, and sustainability. Economic Development and Islamic Finance, 203.

Ahmed, A. (2010). Global financial crisis: An Islamic finance perspective. International Journal of Islamic and Middle Eastern Finance and Management, 3(4), 306320. https://doi.org/10.1108/17538391011093252

Akhisar, I., Tunay, K. B., \& Tunay, N. (2015). The effects of innovations on bank performance: The case of electronic banking services. Procedia-Social and Behavioral Sciences, 195, 369-375. https://doi.org/10.1016/j.sbspro.2015.06.336

Amatus, H., \& Alireza, N. (2015). Financial inclusion and financial stability in Sub-Saharan Africa. International Journal of Social Sciences, 36(1), 2305-4557. https://www.tijoss.com/TIjoss\%2036th\%20Volume/5Amatus.pdf

Ardic, O. P., Imboden, K., \& Latortue, A. (2013). Financial access 2012: Getting to a more comprehensive picture. CGAP and Partners Report, (6).

Alfonse, O. A., \& Florence, M. S. (2012). Credit cards and performance of commercial banks portfolio in Kenya. International Journal of Arts and Commerce, 1(6), 167-173. https://ijac.org.uk/images/frontImages/gallery/Vol._1_No.66_18.pdf

Alvi, M. A., Rafique, A., \& Shehzad, K. (2020). Financial inclusion and bank stability controversy: Evidence from South Asian region. International Journal of Financial Engineering, 7(04), 2050038. https://doi.org/10.1142/S2424786320500383

Al-Smadi, M. O. (2018). The role of financial inclusion in financial stability: lesson from Jordan. Banks \& Bank Systems, 13(4), 31-39. https://www.ceeol.com/search/articledetail?id=741786

Allen, F., Demirguc-Kunt, A., Klapper, L., \& Peria, M. S. M. (2016). The foundations of financial inclusion: Understanding ownership and use of formal accounts. Journal of Financial Intermediation, 27, 1-30. https://doi.org/10.1016/j.jfi.2015.12.003

Ambarkhane, D., Singh, A. S., \& Venkataramani, B. (2016). Measuring financial inclusion of Indian states. International Journal of Rural Management, 12(1), 72-100. https://doi.org/10.1177\%2F0973005216633940

Anatolyevna, M. I., \& Ramilevna, S. L. (2013). Financial stability concept: main characteristics and tools. World Applied Sciences Journal, 22(6), 856-858. https://citeseerx.ist.psu.edu/viewdoc/download?doi=10.1.1.388.2058\&rep=rep1\&ty pe $=$ pdf

Anyanwaokoro, M., \& Ogbu, E. G. (2017). Effect of Commercial Bank Credits on the Performance of Agricultural and Manufacturing Sectors in Nigeria; 1986-2016. Saudi Journal of Economics and Finance (SJEF), 2(4), 122-128. https://saudijournals.com/media/articles/SJEF-24-122-128-c.pdf

Athanasoglou, P. P., Brissimis, S. N., \& Delis, M. D. (2008). Bank-specific, industry-specific and macroeconomic determinants of bank profitability. Journal of international financial Markets, Institutions and Money, 18(2), 121-136. https://doi.org/10.1016/j.intfin.2006.07.001

Babajide, A. A., Adegboye, F. B., \& Omankhanlen, A. E. (2015). Financial inclusion and economic growth in Nigeria. International Journal of Economics and Financial Issues, 5(3), 629-637. http://eprints.covenantuniversity.edu.ng/5426/\#.YOlsEOgzaM8

Beck, T., Demirgüç-Kunt, A., \& Levine, R. (2007). Finance, inequality and the poor. Journal of Economic Growth, 12(1), 27-49. https://link.springer.com/article/10.1007/s10887007-9010-6

Creel, J., Hubert, P., \& Labondance, F. (2015). Financial stability and economic performance. 
Economic Modelling, 48, 25-40. https://doi.org/10.1016/j.econmod.2014.10.025

Crockett, A. (1997). Why is financial stability a goal of public policy? Economic ReviewFederal Reserve Bank of Kansas City, 82, 5-22.

Crockett, A., Ferguson, R. W., Issing, O., Mussa, M., \& Yamaguchi, Y. (2003). Monetary stability, financial stability and the business cycle: five views. Bank for International Settlement (BIS) Papers, No. 18. https://www.bis.org/publ/bppdf/bispap18.pdf

Chhabra, N. (2015). Financial inclusion in India.

Chakrabarty, K. 2. (2013). Financial Inclusion in India: Journey so far and way forward. Keynote Address at the finance inclusion conclave. Organized by CNBC $T V$, 18. https://rbidocs.rbi.org.in/rdocs/Bulletin/PDFs/01SP071013F.pdf

Demirguc-Kunt, A., \& Klapper, L. (2012). Measuring financial inclusion: The global findex database. The World Bank.

Dev, S. M. (2006). Financial inclusion: Issues and challenges. Economic and political weekly, 41(41), 4310-4313. https://www.jstor.org/stable/4418799

Demirguc-Kunt, A., Klapper, L., \& Singer, D. (2017). Financial inclusion and inclusive growth: A review of recent empirical evidence. https://ssrn.com/abstract=2958542

Ditta, A. S. A., \& Saputra, A. (2020). Financial inclusion and banking performance in Indonesia. Journal of Accounting, Finance and Auditing Studies, 6(2), 50-69. https://www.um.edu.mt/library/oar/handle/123456789/54041

Das, T., \& Guha, P. (2015). A study on the differences in the banking parameters between preand post-financial inclusion periods: Some evidence for India. IUP Journal of Bank Management, 14(1), 39-56. https://www.proquest.com/openview/53af456f396f2efd33355c3cc464b4c3/1?pqorigsite $=$ gscholar $\&$ cbl $=54443$

Erol, C., Baklaci, H. F., Aydoğan, B., \& Tunç, G. (2014). Performance comparison of Islamic (participation) banks and commercial banks in Turkish banking sector. EuroMed Journal of Business, 9(2), 114-128. https://doi.org/10.1108/EMJB-05-2013-0024

Frame, W. S., Wall, L. D., \& White, L. J. (2018). Technological change and financial innovation in banking: Some implications for fintech. FRB Atlanta Working Paper No. 2018-11. https://papers.ssrn.com/sol3/papers.cfm?abstract_id=3261732

Hadriche, M. (2015). Banks performance determinants: Comparative analysis between conventional and Islamic banks from GCC countries. International Journal of Economics and Finance, 7(9), 169-177. http://dx.doi.org/10.5539/ijef.v7n9p169

Hamid, M. A., \& Azmi, S. M. (2011). The performance of banking during 2000-2009: Bank Islam Malaysia Berhad and Conventional banking in Malaysia. International Journal of Economics and Management Sciences, 1(1), 09-19.

Haneef, M. A., \& Tahir, S. (2018). Rethinking Islamic Economics and Finance: Taking Stock and Moving Forward. Intellectual Discourse, 26(2), 281-290. https://www.proquest.com/openview/0baaf92281be95c01b959344e6d323e3/1?pqorigsite $=$ gscholar $\& \mathrm{cbl}=826340$

Hariharan, G., \& Marktanner, M. (2012). The growth potential from financial inclusion. ICA Institute and Kennesaw State University, 2(5), 1-12. https://www.atlantafed.org//media/Documents/news/conferences/2012/intl-development/Hariharan.pdf

Ghassan, H. B., \& Taher, F. B. (2013). Financial stability of Islamic and Conventional Banks in Saudi Arabia: Evidence using pooled and panel models. Gulf Research Centre, Cambridge Conference Book GRM 2013, Vol. 2, Islamic Finance: Risk, Stability, Growth. https://mpra.ub.uni-muenchen.de/id/eprint/54472

Ghosh, S., \& Vinod, D. (2017). What constrains financial inclusion for women? Evidence from 
Indian micro data. World 6evelopment, 92, 61. https://doi.org/10.1016/j.worlddev.2016.11.011

Gupte, R., Venkataramani, B., \& Gupta, D. (2012). Computation of financial inclusion index for India. Procedia-Social and Behavioral Sciences, 37, 133-149. https://doi.org/10.1016/j.sbspro.2012.03.281

Houben, A. G., Kakes, J., \& Schinasi, G. J. (2004). Toward a framework for safeguarding financial stability. IMF Working Papers, 2004(101), 3-27. https://www.elibrary.imf.org/view/journals/001/2004/101/article-A001-en.xml

Ikram, I., \& Lohdi, S. (2015). Impact of financial inclusion on banks profitability: An empirical study of banking sector of Karachi, Pakistan. International Journal of Management Sciences and Business Research, 4(10), 88-98.

Jegede, C. A. (2014). Effects of automated teller machine on the performance of Nigerian banks. American Journal of Applied Mathematics and Statistics, 2(1), 40-46.

Johnes, J., Izzeldin, M., \& Pappas, V. (2014). A comparison of performance of Islamic and conventional banks 2004-2009. Journal of Economic Behaviour \& Organization, 103, S93-S107. https://doi.org/10.1016/j.jebo.2013.07.016

Kama, U., \& Adigun, M. (2013). Financial Inclusion in Nigeria: The Journey so Far. SSRN. https://dx.doi.org/10.2139/ssrn.2365209

Kim, D. W., Yu, J. S., \& Hassan, M. K. (2018). Financial inclusion and economic growth in OIC countries. Research in International Business and Finance, 43, 1-14. https://doi.org/10.1016/j.ribaf.2017.07.178

Kim, J. H. (2016). A study on the effect of financial inclusion on the relationship between income inequality and economic growth. Emerging Markets Finance and Trade, 52(2), 498-512. https://doi.org/10.1080/1540496X.2016.1110467

Khan, H. R. (2011). Financial inclusion and financial stability: are they two sides of the same coin. Address by Shri HR Khan, Deputy Governor of the Reserve Bank of India, at BANCON.

Lone, F. A., \& Bhat, U. R. (2019). Does the tag "Islamic" help in customer satisfaction in dual banking sector? Journal of Islamic Marketing, 10(1), 138-149. https://doi.org/10.1108/JIMA-11-2016-0084

Morgan, P., \& Pontines, V. (2014). Financial stability and financial inclusion. ADBI Working Paper 488. https://dx.doi.org/10.2139/ssrn.2464018

Mohseni-Cheraghlou, A. (2017). Financial inclusion and poverty alleviation in muslimmajority countries: the role of Islamic finance and Qard Hassan. In Financial Inclusion and Poverty Alleviation (pp. 141-197). Palgrave Macmillan, Cham.

Mehrotra, A. N., \& Yetman, J. (2015). Financial inclusion-issues for central banks. BIS Quarterly Review March.

Motelle, S., \& Biekpe, N. (2015). Financial integration and stability in the Southern African development community. Journal of Economics and Business, 79, 100-117. https://doi.org/10.1016/j.jeconbus.2015.01.002

Mirza, N., Rahat, B., \& Reddy, K. (2015). Business dynamics, efficiency, asset quality and stability: The case of financial intermediaries in Pakistan. Economic Modelling, 46, 358-363. https://doi.org/10.1016/j.econmod.2015.02.006

Nazer, (2017). Impact analysis of Islamic finance on financial inclusion and economic growth in selected Muslim countries: OIC. International Journal of Economics, Management and Accounting, 26(2), 393-414. https://journals.iium.edu.my/enmjournal/index.php/enmj/article/view/512

Nawaz, T. (2018). Lifting the lid on financial inclusion: Evidence from emerging economies. 
International Journal of Financial $\quad$ Studies, 6(2), 59. https://doi.org/10.3390/ijfs6020059

Neaime, S., \& Gaysset, I. (2018). Financial inclusion and stability in MENA: Evidence from poverty and inequality. Finance Research Letters, 24, 230-237. https://doi.org/10.1016/j.frl.2017.09.007

Oranga, O. J., \& Ondabu, I. T. (2018). Effect of financial inclusion on financial performance of banks listed at the Nairobi securities exchange in Kenya. International Journal of Scientific and Research Publications, 8(5), 624-649.

Olaniyi, E. (2017). Back to the land: The impact of financial inclusion on agriculture in Nigeria. Iranian Economic Review, 21(4), 885-903. https://dx.doi.org/10.22059/ier.2017.64086

Ozili, P. K. (2018). Impact of digital finance on financial inclusion and stability. Borsa Istanbul Review, 18(4), 329-340. https://doi.org/10.1016/j.bir.2017.12.003

Park, C. Y., \& Mercado, R. (2018). Financial inclusion: New measurement and cross-country impact assessment. SSRN. https://dx.doi.org/10.2139/ssrn.3199427

Petersen, M. A., \& Rajan, R. G. (1995). The effect of credit market competition on lending relationships. The Quarterly Journal of Economics, 110(2), 407-443. https://doi.org/10.2307/2118445

Popovska, J. (2014). Modelling financial stability: The case of the banking sector in Macedonia. Journal of Applied Economics and Business, 2(1), 68-91. http://www.aebjournal.org/articles/0201/020104.pdf

Rashid, A. (2020). Nexus between Economic Growth, Investment, and Islamic Banking Development: The case of Dual Banking System. Journal of Islamic Business and Management, 10(2), 368-389.

Rangarajan, C. (2008). Report of the committee on financial inclusion. Ministry of Finance, Government of India.

Ramlan, H., \& Adnan, M. S. (2016). The profitability of Islamic and conventional bank: Case study in Malaysia. Procedia Economics and Finance, 35, 359-367. https://doi.org/10.1016/S2212-5671(16)00044-7

Rahim, S. R. M., \& Zakaria, R. H. (2013). Comparison on stability between Islamic and conventional banks in Malaysia. Journal of Islamic Economics, Banking and Finance, 9(3), 131-149. https://platform.almanhal.com/Files/2/40149

Rozzani, N., \& Rahman, R. A. (2013). Camels and performance evaluation of banks in Malaysia: Conventional versus Islamic. Journal of Islamic Finance and Business Research, 2(1), 36-45.

Safiullah, M. (2010). Superiority of conventional banks \& Islamic banks of Bangladesh: A comparative study. International Journal of Economics and Finance, 2(3), 199-207. https://pdfs.semanticscholar.org/0fe8/e16d3bc35e7ccf94f6e566ac58c144252935.pdf

Sahay, R., Čihák, M., N'Diaye, P., \& Barajas, A. (2015). Rethinking financial deepening: Stability and growth in emerging markets. Revista de Economía Institucional, 17(33), 73-107.

Sarma, M. (2008). Index of financial inclusion (No. 22259; Finance Working Papers). East Asian Bureau of Economic Research.

Sarma, M., \& Pais, J. (2011). Financial inclusion and development. Journal of international development, 23(5), 613-628. https://doi.org/10.1002/jid.1698

Sarma, M. (2012). Index of financial inclusion: A measure of financial sector inclusiveness. Centre for International Trade and Development, School of International Studies, Working Paper Jawaharlal Nehru University. https://financeand-trade.htw- 
berlin.de/fileadmin/HTW/Forschung/Money_Finance_Trade_Development/working_pa per series/wp 072012 Sarma Index-of-Financial-Inclusion.pdf

Seman, J. A. (2016). Financial inclusion: The role of financial system and other determinants. Doctoral dissertation, University of Salford.

Sharma, A., \& Kukreja, S. (2013). An analytical study: Relevance of financial inclusion for developing nations. International Journal of Engineering and Science, 2(6), 15-20.

Shiimi, I. (2010). Financial inclusion-an imperative towards vision 2030. Annual address by the Governor of the Reserve Bank of Namibia, 28.

Shihadeh, F. H., Hannon, A. M., Guan, J., Ul Haq, I., \& Wang, X. (2018). Does financial inclusion improve the banks' performance? Evidence from Jordan. In Global tensions in financial markets. Emerald Publishing, 117-138 https://doi.org/10.1108/S0196$\underline{382120170000034005}$

Shinkafi, A. A., Yahaya, S., \& Sani, T. A. (2019). Realizing financial inclusion in Islamic finance. Journal of Islamic Marketing, 11(1), 143-160. https://doi.org/10.1108/JIMA-02-2017-0020

Tita, A. F., \& Aziakpono, M. J. (2017). The relationship between financial inclusion and income inequality in sub-Saharan Africa: Evidence from disaggregated data. African Review of Economics and Finance, 9(2), 30-65. https://www.ajol.info/index.php/aref/article/view/164547

Uddin, A., Chowdhury, M. A. F., \& Islam, M. N. (2017). Determinants of financial inclusion in Bangladesh: Dynamic GMM \& quantile regression approach. The Journal of Developing Areas, 51(2), 221-237. https://doi.org/10.1353/jda.2017.0041

Ussif, D. R., \& Yussif, U. (2020). Establishing Islamic Banking and Financing (IBF) in Ghana: Issues challenges and prospects. Global Scientific Journals, 8(5). 1805-1821.

Umar, U. H., Ado, M. B., \& Ayuba, H. (2019). Is religion (interest) an impediment to Nigeria's financial inclusion targets by the year 2020? A qualitative inquiry. Qualitative Research in Financial Markets, 12(3), 283-300. https://doi.org/10.1108/QRFM-012019-0010

Wairimu, K. D. (2020). Financial inclusion and banks stability of commercial banks listed in Nairobi securities exchange. Kenyatta University. https://irlibrary.ku.ac.ke/bitstream/handle/123456789/21832/Financial\%20inclusion........pdf ?sequence $=1$

Yousef, M. H. (2020). The impact of financial inclusion on the performance of traditional banks: An analytical study on conventional banks listed on the Palestine Stock Exchange using the CAMELS model, 8(4), 01-36. https://doi.org/10.53671/ptukrj.v8i4.95

Zins, A., \& Weill, L. (2016). The determinants of financial inclusion in Africa. Review of Development Finance, 6(1), 46-57. https://doi.org/10.1016/j.rdf.2016.05.001 